Editorial

\title{
Ecosystem Engineers in the World Coasts: Case Studies and Conceptual Linkages
}

\author{
Jorge L. Gutiérrez ${ }^{1,2}$ (i) \\ 1 Instituto de Geología de Costas y del Cuaternario (IGCyC, UNMdP/CIC) \& Instituto de Investigaciones \\ Marinas y Costeras (IIMyC, CONICET/UNMdP), Facultad de Ciencias Exactas y Naturales, Universidad \\ Nacional de Mar del Plata, Mar del Plata B7602AYL, Argentina; jgutierrez@grieta.org.ar \\ 2 Grupo de Investigación y Educación en Temas Ambientales (GrIETA), Estación Biológica Las Brusquitas, \\ San Eduardo del Mar B7783ADE, Argentina
}

Received: 4 June 2020; Accepted: 12 June 2020; Published: 15 June 2020

\begin{abstract}
Research on physical ecosystem engineering-i.e., the structural modification of environments by organisms-has flourished during the last two decades. At present, the importance of physical ecosystem engineers for the biodiversity and the functioning of ecosystems is well recognized by scientists. This Special Issue contains fifteen papers that illustrate the diversity of physical ecosystem engineering processes that occur in the world coastal habitats-from coastal dunes to the shallow subtidal zone. It includes 2 reviews comparing ecosystem engineering attributes and impacts across taxa and 13 case studies that inform our general understanding of the variation in engineering impacts, compound engineering effects, novel engineering interactions, and engineered structural legacies.
\end{abstract}

Keywords: physical ecosystem engineering; dunes; mangroves; salt marsh; seagrass; rocky shore; mudflats; habitat cascades; novel interactions; structural legacies

Physical ecosystem engineering—or, simply, ecosystem engineering—is the structural modification of environments due to the presence or activities of organisms [1-3]. This concept was coined in 1994 by Clive Jones and colleagues [1] in an attempt to encompass a variety of superficially disparate ecological phenomena (e.g., trees as living spaces, dam building by beavers, the creation of soil macropores by earthworms) not addressed by the historical focus of ecology on trophic relations (i.e., predation, resource competition, food webs, energy flow, nutrient cycling and the like; see also [4]). Despite early criticisms and debate, the concept is now widely used across ecological subdisciplines [3,5]; the earth sciences [6,7]; and applied domains, such as environmental conservation, ecological restoration, and the growing field of nature-based environmental solutions [8-10].

The use of the physical ecosystem engineering concept is particularly widespread in marine ecology (Figure 1), where it is proving important to characterize the impacts of marine foundation species (such as corals, mangroves, or kelps; see [11]) to describe species interactions (e.g., positive effects, cascading impacts) and to unravel the physical effects of organisms on benthic species compositions and functioning (e.g., sediment-mediated species interactions, effects on hydrodynamics and sediment transport) among other research focuses. This Special Issue contains 15 papers contributed by marine ecologists from all across the globe. They deal with prominent groups of coastal engineers (macroalgae, vascular plants, benthic invertebrates, and fish) in habitats ranging from the supralittoral to the shallow subtidal, including dunes, mangrove forests, salt marshes, seagrass meadows, mudflats, rocky shores, and reefs. From their joint analyses, the papers in this volume can be grouped within the following general themes: 


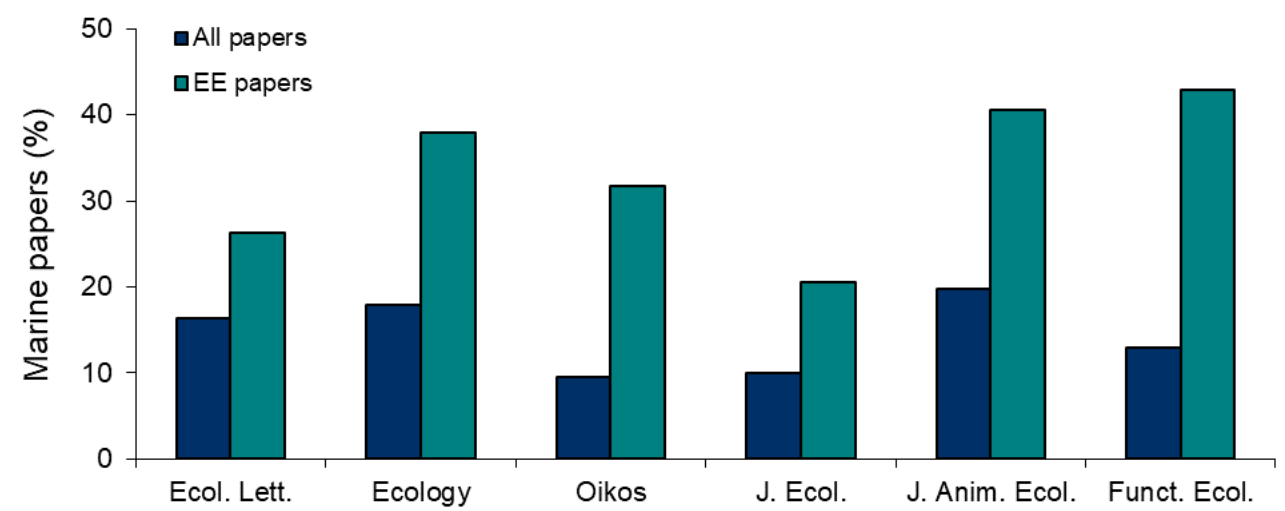

Figure 1. Marine studies as the percentage of all papers published in six general ecological journals (All papers) and as the percentage of all the ecosystem engineering papers published in these same journals (EE papers). The analysis considered studies published from 1994 (i.e., when the foundational paper on the ecosystem engineering concept was published; see [1]) to 2019. EE papers were defined as those including the terms "ecosystem engineer" or "ecosystem engineering" in their title and/or abstract. Marine papers were defined as those including any of the following words in their title and/or abstract: "marine", "coastal”, "sea”, "reef", "saltmarsh", "salt marsh", "mangrove", "estuary", "rocky shore", "mudflat", “mud flat", “tidal flat", "seamount”, “deep sea”, “beach", “sand flat", “sandflat”, "intertidal", and "subtidal". Searches were conducted with the search tools available in the websites of these journals.

(a) Sources of Variation in the Impacts of Particular Ecosystem Engineers

Four studies in this volume deal with variations in the impact of particular ecosystem engineers as related to structural attributes (e.g., cover, size, age) and local environmental conditions (e.g., water flow, particulate transport), or temporal scale. Pocklington et al. [12] show that varying degrees of cover loss in the canopy-forming algae, Hormosira banksii, affect abiotic conditions (temperature, light incidence) and assemblage composition at intertidal rocky platforms in Victoria, Australia. Chava et al. [13] show that the variation in size and age of the foliose red alga, Phycodrys rubens, affects the composition of epibiotic assemblages in shallow subtidal areas of the White Sea, Russia. Arkema and Samhouri [14] illustrate that kelp (Macrocystis pyrifera) blades located in forest edges are exposed to higher flow velocities and particulate transport than those in the forest interiors, which favors and the abundance and growth of a suspension-feeding, epibiotic bryozoan (Membranipora) off the coast of California, USA.

(b) Interspecific Variation in Engineering Attributes and Effects

Three studies evaluate variation engineering attributes and impacts across species that co-occur in particular habitat types. Hacker et al. [15] compared the functional morphology and sand accretion of four co-occurring dune grass species (Ammophila breviligulata, Panicum amarum, Spartina patens, and Uniola paniculata) along the barrier islands of the Outer Banks, USA. Thomsen and South [16] characterized community composition and attachment networks in the rocky shores of south-eastern New Zealand, comparing bull kelp (Durvillaea spp.) stands with areas that become dominated by other macroalgal foundation species (Cystophora spp. and Undaria pinnatifida) after natural and experimental bull kelp losses. Moreover, Ndlovhu et al. [17] compared the composition, prevalence, and impact of endolithic microbes infecting the shells of two dominant intertidal mussel species in South Africa (Perna perna and Mytilus galloprovincialis).

(c) Compound Ecosystem Engineering Effects

The study of compound engineering impacts on other organisms-i.e., impacts mediated by two or more interacting engineers-has gained momentum over the last decade, not least because of the increased appreciation by ecologists of the occurrence and importance of habitat cascades (i.e., positive engineering effects on secondary to nth order engineers that, in turn, create favorable 
habitat for other organisms; see [18]). Here, Zhang and Silliman [19] report a habitat cascade where eelgrass (Zostera marina) increase the growth and survival of pen clams (Atrina rigida) that, in turn, increase the overall community diversity by providing hard substrate to macroalgae and fouling invertebrates in the seagrass beds of North Carolina, U.S.A. Habitat cascades are also evident in the attachment networks described by Thomsen and South [16] for rocky shores in southeastern New Zealand (see above). In that example, large macroalgal species that act as primary foundation species serve as substrate for epiphytes (i.e., secondary foundation species) that provide living space to other organisms. Additionally, a study by my colleagues and I [20] in southwestern Atlantic rocky shores (Buenos Aires Province, Argentina) illustrates a distinctive form of compound engineering impact, provisionally termed co-engineering, where primary engineers-in our example, mussels, Brachidontes rodriguezii—create a habitat for secondary engineers, epibiotic algae, Porphyra sp., and they both have concurrent, joint impacts on other organisms, including amphipods, Hyale grandicornis.

(d) Concurrent Engineering and Non-Engineering Impacts

The net effect of species on their ecosystems and communities usually results from a combination of distinct concurrent mechanisms [21]. Red groupers (Epinephelus morio) are territorial predatory fishes that inhabit karst solution holes at Florida Bay, USA. They also act as engineers by excavating sediment and detritus that would otherwise accumulate in solution holes. By means of removal experiments and long-term observations, Ellis [22] illustrates that red grouper presence generally has positive effects on the abundance, richness, and diversity of fishes and invertebrates occurring in solution holes, which can partly be attributable to increased habitat availability via sediment and detritus removal.

\section{(e) Ecosystem Engineers as Drivers of Novel Species Interactions}

As some species shift in their distributional range in response to climate change, novel species interactions are expected to occur. Two studies here evaluate novel engineering interactions in Florida, USA, resulting from the poleward migration of tropical species in response to global warming. Walker et al. [23] found that the expansion of mangroves into salt marsh habitats is not altering soil properties, invertebrate communities, and the consumptive effects of large predators at ecotones, in spite of structural differences among vegetation types. Cannizzo et al. [24] shows that the northward range expansion of a mangrove-associated arboreal crab, Aratus pisonii, and the concomitant colonization of structurally-different salt marsh habitats increases the incidence and risk of ritualistic aggressive behavior in this species.

\section{(f) Structural Legacies}

The structures made by physical ecosystem engineers can persist after organismal death, thus having legacy effects on abiotic conditions and other organisms (see [25]). Commito et al. [26] shows that the decline of mussel (Mytilus edulis) beds in the Gulf of Maine, USA, and the concomitant accumulation of shells and fragments in the seabed affects the transport of sediment, meiofauna, and macrofauna. Moreover, Bagur et al. [27] illustrates that the protected habitat within vacant boreholes of the bivalve (Petricola dactylus) are critical for the maintenance of biodiversity in a physically harsh low intertidal platform in the northern Argentinean Patagonia.

(g) Integration and Synthesis

The cross-system and cross-taxa reviews of engineers and their impacts are fundamental for conceptual progress and generalization in the field [5]. Two studies in this volume tackle the task. Pillay [28] reviews abiotic and biotic context dependencies in the ecological impacts of thalassinidean shrimp - a major group of ecosystem engineers amongst the coastal soft-sediment benthos. Bruschetti [29] reviews the effect of reef-building polychaetes on shallow-water benthic communities, ecosystem functioning, and services.

Collectively, the papers in this Special Issue illustrate the variety of topics and study systems that are currently of interest for scientists studying ecosystem engineers along the world's coasts. 
The case studies included in this volume [12-17,19,20,22-24,26,27] inform a number of general themes in ecosystem engineering research (see a-g above) and other fields as well (e.g., sediment transport, parasitic interactions, agonistic behavior in animals $[15,17,24,26])$. I hope these case studies serve as inspiration for others and, especially, as raw material for future generalization and synthesis in the same way that previous case studies paved the road for the synthetic reviews presented in this volume $[28,29]$.

Acknowledgments: I thank Christian Wild for inviting me to edit this Special Issue and the authors of all the submitted papers for their contributions. My special thanks the reviewers that kindly contributed to the quality of the papers by sharing their time and expertise.

Conflicts of Interest: The authors declare no conflict of interest.

\section{References}

1. Jones, C.G.; Lawton, J.H.; Shachak, M. Organisms as ecosystem engineers. Oikos 1994, 69, 373-386. [CrossRef]

2. Jones, C.G.; Lawton, J.H.; Shachak, M. Positive and negative effects of organisms as physical ecosystem engineers. Ecology 1997, 78, 1946-1957. [CrossRef]

3. Jones, C.G.; Gutiérrez, J.L. On the purpose, meaning, and usage of the ecosystem engineering concept. In Ecosystem Engineers: Plants to Protists; Cuddington, K., Byers, J.E., Wilson, W.G., Hastings, A., Eds.; Academic Press: New York, NY, USA, 2007; pp. 3-24.

4. Gutiérrez, J.L.; Jones, C.G. Ecosystem engineers. In Encyclopedia of Life Sciences; John Wiley \& Sons: Chichester, UK, 2008. [CrossRef]

5. Wright, J.P.; Jones, C.G. The concept of organisms as ecosystem engineers ten years on: Progress, limitations, and challenges. BioScience 2006, 56, 203-209. [CrossRef]

6. Butler, D.R.; Sawyer, C.F. Introduction to the special issue-Zoogeomorphology and ecosystem engineering. Geomorphology 2012, 157, 1-5. [CrossRef]

7. Gurnell, A.M.; Bertoldi, W.; Corenblit, D. Changing river channels: The roles of hydrological processes, plants and pioneer fluvial landforms in humid temperate, mixed load, gravel bed rivers. Earth-Sci. Rev. 2012, 111, 129-141. [CrossRef]

8. Byers, J.E.; Cuddington, K.; Jones, C.G.; Talley, T.S.; Hastings, A.; Lambrinos, J.G.; Crooks, J.A.; Wilson, W.G. Using ecosystem engineers to restore ecological systems. Trends Ecol. Evol. 2006, 21, 493-500. [CrossRef]

9. Mosepele, K.; Moyle, P.B.; Merron, G.S.; Purkey, D.R.; Mosepele, B. Fish, floods, and ecosystem engineers: Aquatic conservation in the Okavango Delta, Botswana. BioScience 2009, 59, 53-64. [CrossRef]

10. Borsje, B.W.; van Wesenbeeck, B.K.; Dekker, F.; Paalvast, P.; Bouma, T.J.; van Katwijk, M.M.; de Vries, M.B. How ecological engineering can serve in coastal protection. Ecol. Eng. 2011, 37, 113-122. [CrossRef]

11. Dayton, P.K. Toward an understanding of community resilience and the potential effects of enrichments to the benthos at McMurdo Sound, Antarctica. In Proceedings of the Colloquium on Conservation Problems in Antarctica; Parker, B.C., Ed.; Allen Press: Lawrence, KS, USA, 1972; pp. 81-96.

12. Pocklington, J.B.; Keough, M.J.; O’Hara, T.D.; Bellgrove, A. The influence of canopy cover on the ecological function of a key autogenic ecosystem engineer. Diversity 2019, 11, 79. [CrossRef]

13. Chava, A.; Artemieva, A.; Yakovis, E. Plant part age and size affect sessile macrobenthic assemblages associated with a foliose red algae Phycodrys rubens in the white sea. Diversity 2019, 11, 80. [CrossRef]

14. Arkema, K.K.; Samhouri, J.F. Living on the edge: Variation in the abundance and demography of a kelp forest epibiont. Diversity 2019, 11, 120. [CrossRef]

15. Hacker, S.D.; Jay, K.R.; Cohn, N.; Goldstein, E.B.; Hovenga, P.A.; Itzkin, M.; Moore, L.J.; Mostow, R.S.; Mullins, E.V.; Ruggiero, P. Species-specific functional morphology of four US Atlantic coast dune grasses: Biogeographic implications for dune shape and coastal protection. Diversity 2019, 11, 82. [CrossRef]

16. Thomsen, M.S.; South, P.M. Communities and attachment networks associated with primary, secondary and alternative foundation species; a case study of stressed and disturbed stands of southern bull kelp. Diversity 2019, 11, 56. [CrossRef]

17. Ndhlovu, A.; McQuaid, C.D.; Nicastro, K.; Marquet, N.; Gektidis, M.; Monaco, C.J.; Zardi, G. Biogeographical patterns of endolithic infestation in an invasive and an indigenous intertidal marine ecosystem engineer. Diversity 2019, 11, 75. [CrossRef] 
18. Thomsen, M.S.; Wernberg, T.; Altieri, A.; Tuya, F.; Gulbransen, D.; McGlathery, K.J.; Holmer, M.; Silliman, B.R. Habitat cascades: The conceptual context and global relevance of facilitation cascades via habitat formation and modification. Integr. Comp. Biol. 2010, 50, 158-175. [CrossRef] [PubMed]

19. Zhang, Y.S.; Silliman, B.R. A facilitation cascade enhances local biodiversity in seagrass beds. Diversity 2019, 11, 30. [CrossRef]

20. Gutiérrez, J.L.; Bagur, M.; Palomo, M.G. Algal epibionts as co-engineers in mussel beds: Effects on abiotic conditions and mobile interstitial invertebrates. Diversity 2019, 11, 17. [CrossRef]

21. Gutiérrez, J.L.; Jones, C.G.; Sousa, R. Toward an integrated ecosystem perspective of invasive species impacts. Acta Oecol. 2014, 54, 131-138. [CrossRef]

22. Ellis, R.D. Red grouper (Epinephelus morio) shape faunal communities via multiple ecological pathways. Diversity 2019, 11, 89. [CrossRef]

23. Walker, J.E.; Angelini, C.; Safak, I.; Altieri, A.H.; Osborne, T.Z. Effects of changing vegetation composition on community structure, ecosystem functioning, and predator-prey interactions at the saltmarsh-mangrove ecotone. Diversity 2019, 11, 208. [CrossRef]

24. Cannizzo, Z.J.; Nix, S.K.; Whaling, I.C.; Griffen, B.D. Individual morphology and habitat structure alter social interactions in a range-shifting species. Diversity 2019, 11, 6. [CrossRef]

25. Jones, C.G.; Gutiérrez, J.L.; Byers, J.E.; Crooks, J.A.; Lambrinos, J.G.; Talley, T.S. A framework for understanding physical ecosystem engineering by organisms. Oikos 2010, 119, 1862-1869. [CrossRef]

26. Commito, J.A.; Jones, B.R.; Jones, M.A.; Winders, S.E.; Como, S. After the fall: Legacy effects of biogenic structure on wind-generated ecosystem processes following mussel bed collapse. Diversity 2019, 11, 11. [CrossRef]

27. Bagur, M.; Gutiérrez, J.L.; Arribas, L.P.; Palomo, M.G. Vacant bivalve boreholes increase invertebrate species richness in a physically harsh, low intertidal platform. Diversity 2019, 11, 39. [CrossRef]

28. Pillay, D. Ecosystem engineering by thalassinidean crustaceans: Response variability, contextual dependencies and perspectives on future research. Diversity 2019, 11, 64. [CrossRef]

29. Bruschetti, M. Role of reef-building, ecosystem engineering polychaetes in shallow water ecosystems. Diversity 2019, 11, 168. [CrossRef]

(C) 2020 by the author. Licensee MDPI, Basel, Switzerland. This article is an open access article distributed under the terms and conditions of the Creative Commons Attribution (CC BY) license (http://creativecommons.org/licenses/by/4.0/). 